\title{
Concentration of Metals in Native and Invasive Species of Fish in the Fluvial-Lagoon-Deltaic System of the Palizada River, Campeche
}

\author{
María del Refugio Castañeda-Chávez ${ }^{1, *(\mathbb{D})}$, Fabiola Lango-Reynoso ${ }^{1}$, Gabycarmen Navarrete-Rodríguez ${ }^{1}$ (D) \\ and Armando Toyokazu Wakida-Kusunoki ${ }^{2}$ \\ 1 Tecnológico Nacional de México, Instituto Tecnológico de Boca del Río, Carretera Veracruz, \\ Boca del Río CP 94290, Mexico; fabiolalango@bdelrio.tecnm.mx (F.L.-R.); \\ gabycarmennavarrete@bdelrio.tecnm.mx (G.N.-R.) \\ 2 Instituto Nacional de Pesca y Acuacultura, Centro Regional de Investigación Pesquera de Yucalpetén, \\ Boulevard del Pescador s/n Esquina Antigua Carretera a Chelem, Mérida CP 97320, Mexico; \\ armando.wakida@inapesca.gob.mx \\ * Correspondence: mariacastaneda@bdelrio.tecnm.mx; Tel.: +52-(229)158-99-35
}

\section{check for} updates

Citation: Castañeda-Chávez, M.d.R. Lango-Reynoso, F.; NavarreteRodríguez, G.; Wakida-Kusunoki, A.T. Concentration of Metals in Native and Invasive Species of Fish in the Fluvial-Lagoon-Deltaic System of the Palizada River, Campeche. Fishes 2021, 6, 72. https://doi.org/10.3390/ fishes 6040072

Academic Editors: Ana Rita Vieira and Bernardo Baldisserotto

Received: 26 July 2021

Accepted: 30 November 2021

Published: 3 December 2021

Publisher's Note: MDPI stays neutral with regard to jurisdictional claims in published maps and institutional affiliations.

Copyright: (c) 2021 by the authors. Licensee MDPI, Basel, Switzerland. This article is an open access article distributed under the terms and conditions of the Creative Commons Attribution (CC BY) license (https:// creativecommons.org/licenses/by/ $4.0 /)$.

\begin{abstract}
Aquatic organisms, such as fish, are important indicators of the bioavailability of metals in coastal environments, demonstrating the capacity of different species to bioaccumulate these metallic elements. The fluvial-lagoon system of the Palizada River is an important ecosystem for its terrestrial and aquatic biological diversity where fishing is an important productive activity in this system. The objective of this research was to evaluate the concentration of $\mathrm{Pb}$ and $\mathrm{Cd}$ in the muscle tissue of native and invasive fish species in this area. For this, the digestion of fish muscle samples was carried out with a CEM MARS 5 Digestion Microwave System, while the quantification of metals was performed with an atomic absorption equipment. All analysis muscle samples from native and invasive fish showed $\mathrm{Pb}$ and $\mathrm{Cd}$ in their content. By sampling site there was a statistically significant difference $(p<0.05)$, with a maximum $\mathrm{Pb}$ concentration of $7.760 \mu \mathrm{g} \mathrm{g}^{-1}$ at the LLAR site (Laguna Larga). In terms of species, the maximum Cd concentration was obtained in the Cyprinus carpio with $6.630 \pm 0.127$ and in Pterygoplichthus pardalis with $6.547 \pm 0.873 \mu \mathrm{g} \mathrm{g}^{-1}$ (dry weight). The presence of metals such as $\mathrm{Pb}$ and $\mathrm{Cd}$ in muscle tissue of native and invasive fish species represents an important bioindicator of environmental exposure in the study area and a potential risk to public health, as these species are commonly consumed.
\end{abstract}

Keywords: native and invasive species; trophic level; bioavailability; metals; fluvial-lagoondeltaic system

\section{Introduction}

Metals follow different pathways and cycles in the environment, some of them undergo transformations and are distributed in trace concentrations not harmful for most forms of life [1]. Furthermore, the accumulation of some of these metals in tissues of aquatic organisms is mainly influenced by the concentrations of such elements in their environment, both in water and sediments [2].

Metals are naturally present in soil and rocks as trace elements. Due to various anthropogenic impacts, these elements increase in concentration when they enter aquatic ecosystems by leaching. They directly or indirectly contaminate water supplies and thus become part of food chains posing a potential risk to public health through the consumption of organisms such as fish [3,4].

Monitoring studies of aquatic organisms in Mexico have been used to determine the concentration of metals that generally focus on benthic organisms and habitats, including bivalves such as oysters, mussels [4-8], and crustaceans $[4,9,10]$. However, the use of other 
free-living aquatic organisms such as fish can also be an effective monitoring tool. As these organisms are long-lived and mobile, they are good indicators for assessing water quality [11,12].

Different native fish species help define the biological integrity of a site as a measure of ecosystem health [13]. In contrast, invasive fish are a threat to native biodiversity through competition for food, nesting sites, predation, introduction of infectious agents, and displacement of native species. However, their presence is not considered in the management plans generated by headquarters of governmental institutions in Mexico City (INAPESCA, CONANP, PROFEPA, SEMARNAT, IMTA and SENASICA of SAGARPA) for the protected areas of southeastern Mexico $[14,15]$. The deltaic lagoon system of the Palizada River, located in the Laguna de Términos in the Flora and Fauna Protection Area in the state of Campeche, is one of the ecosystems most affected by the presence of the invasive Amazon sailfin catfish, Pterygoplichthys pardalis. The presence of this invasive fish causes an environmental and socio-economic impact on both fisheries and biodiversity loss, as well as on fishing as a source of employment and economic income [16]. Other impacts present in the Palizada River system are due to the fact that it is a tributary of the Usumacinta River, which receives polluted water discharged by industrial and oil activities along its entire course through southeastern Mexico.

Species such as the Amazon sailfin catfish have been reported by Mendoza et al. $[17,18]$ to be one of the greatest threats to biodiversity, competing with and preying on native fish species in Mexico's inland aquatic ecosystems. Exploitation of the Amazon sailfin catfish is one of the measures implemented to reduce the effect of invasive species and the problems it generates. For this reason, the Mexican National Commission for Aquaculture and Fisheries promotes its capture for human consumption and also its commercial exploitation in various productive sectors of the country [19]. Commercial fishing also promotes the use of introduced species of the family Cichlidae and some species of the family Cyprinidae [20].

In Mexico, the consumption of Amazon sailfin catfish is promoted, mainly among the inhabitants of the states of Chiapas and Tabasco [21]. The use of control strategies for this species has been incorporated into various agricultural activities such as agriculture, livestock, and aquaculture $[19,21]$. The presence of pollutants, such as metals in aquatic ecosystems, causes both native and invasive species to be exposed to these elements, which are incorporated into different aquatic ecosystems, such as rivers, lakes, and coastal lagoons in Mexico. This work is the first study on the determination of metals in native and invasive species in the Palizada River lagoon system, since many studies have focused on the analysis of pollutants in the Laguna de Términos, adjacent to this lagoon river system. The objective of this research was to evaluate the concentration and variation of $\mathrm{Pb}$ and $\mathrm{Cd}$ levels in muscle tissue among native and invasive fish species in the fluvial-lagoon-deltaic system of the Palizada River, Campeche.

\section{Materials and Methods}

\subsection{Study Area}

The Palizada River is located at the western end of the Laguna de Términos, between $18^{\circ} 29^{\prime} 13^{\prime \prime}$ and $18^{\circ} 29^{\prime} 04^{\prime \prime} \mathrm{N}$ and $91^{\circ} 44^{\prime} 36^{\prime \prime}$ and $91^{\circ} 51^{\prime} 31^{\prime \prime} \mathrm{W}$; where most of the year the discharge of water from the mouth of this river flows almost directly into the Campeche shelf [22]. This river is the largest and narrowest branch, east of the Usumacinta River. This tributary also belongs to the larger basin of the Grijalva-Usumacinta system, from which it is derived to form the fluvial-lagoon-deltaic system of the Palizada River [22,23]. The system also forms part of the hydrological network of the Mexcalapa and GrijalvaUsumacinta rivers, which has an average annual contribution to the Laguna de Términos of $9.6 \times 10 \mathrm{~m}^{3}$, accounting for almost $70 \%$ of the total water input to the lagoon [24].

The water inputs to the Palizada system are the Blanco stream, until it joins the Viejo River and flows into the Laguna del Este, as well as small streams from the Piñas and Marentes rivers in the east, which finally flow into the Barra de Boca Chica towards the 
Laguna de Términos [22]. The Palizada system has several meanders that run through a low, swampy alluvial plain covered with vegetation [22,23].

\subsection{Sampling Sites and Collection of Specimens}

Sampling sites were selected on the basis of a prospective visit to the study area. Subsequently, 19 final sampling sites were selected and georeferenced to cover a homogeneous distribution in the study area. The selection of sampling sites tried to cover river and lake areas (Figure 1). Samples were collected during three climatic seasons of the region, identified as: dry, March-May; rainy, June-September; and north winds, October-February [23,24].
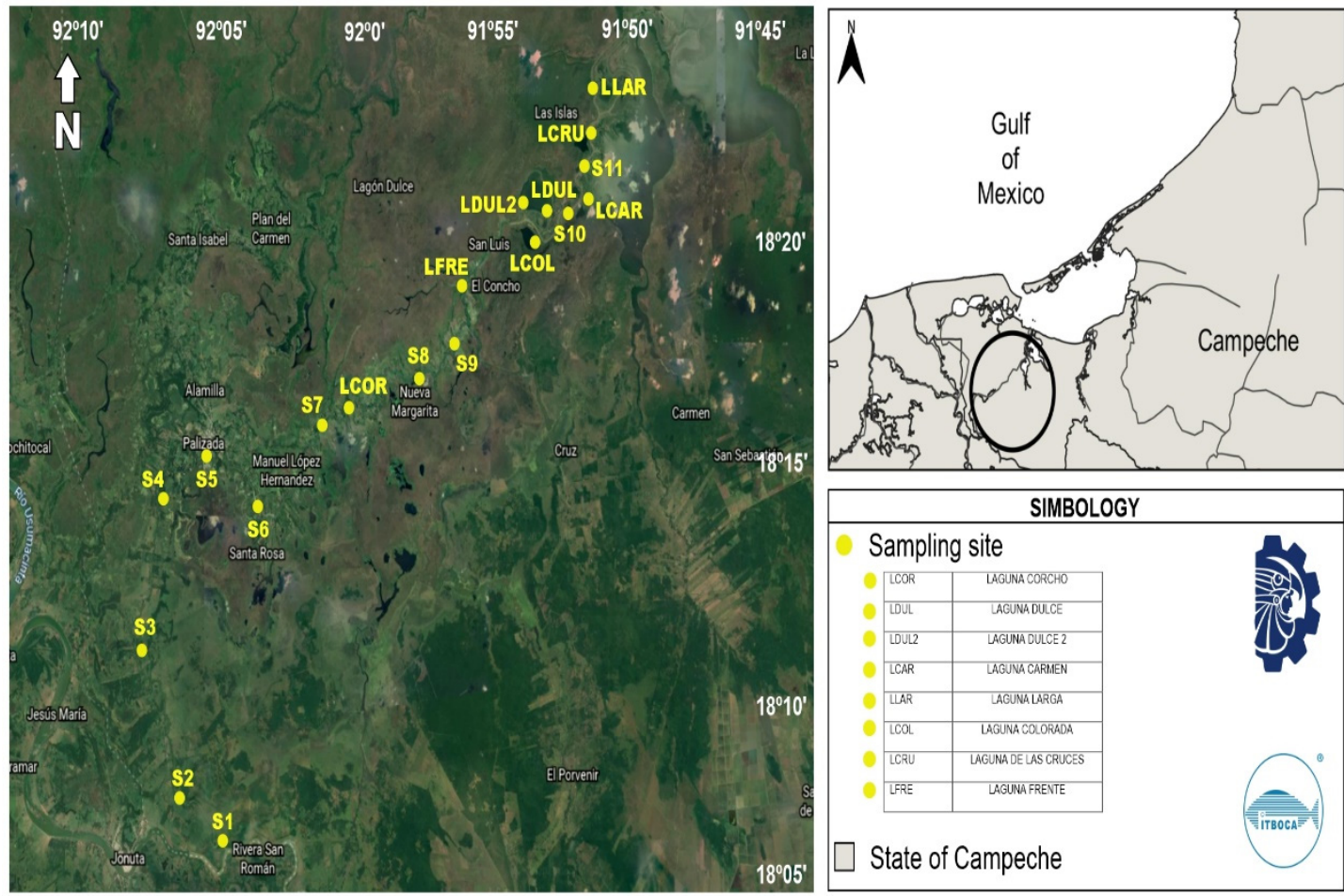

Figure 1. Sampling sites of fish species in the fluvial-lagoon-deltaic system of the Palizada River, Campeche.

Specimens of seven native and invasive fish species were collected in the study area, the invasive species were: Amazon sailfin catfish Pterygoplichthus pardalis, Common carp Cyprinus carpio, Grass carp Ctenopharyngodon idealla, and Nile tilapia Oreochromis niloticus. Native species include: Mayan cichlid Mayaheros urophthalmus, Twoband cichlid Vieja bifasciata, Bay snook Petenia splendida. For the capture of introduced and native species of the family Cichlidae (tilapia and mojarra), trawls with a minimum mesh size of 76.2 millimetres ( 3 inches) were used as fishing gear. For the rest of the native and some introduced species of the Cyprinidae family, a minimum mesh size of 127.0 millimetres (5 inches) was used [20]. Approximately five fish were captured at each sampling site during each season, all of which were approximately $15-20 \mathrm{~cm}$ and 230-300 g in commercial size. Species identification of collected specimens was carried out following the criteria of Miller et al. [25] and Wakida-Kusunoki and Amador del Angel [26]. The collected organisms were placed in hermetically sealed and pre-labelled polyethylene bags. They were then stored under refrigeration at a maximum temperature of approximately $4{ }^{\circ} \mathrm{C}$ and kept under these conditions until processing in the laboratory.

\subsection{Ethics and Animal Use}

The handling of specimens in this research was conducted in accordance with the Code of Practice for the Housing and Care of Animals used in scientific procedures. This document was issued on 14 April 2016 and under Section 1 of the Animals (Scientific 
Procedures) Act. Fish were killed by a severe blow to the head followed by the destruction of the brain. Furthermore, taking into account the above guidelines, this research, the planning and execution of this work complied with the commonly accepted '3Rs' guidelines: Replacement of animals with alternatives wherever possible; Reduction of the number of animals used; and Refinement of experimental conditions and procedures to minimise harm to the animals.

\subsection{Sample Processing}

Processing of samples obtained in the field was carried out at the Laboratorio de Investigación de Recursos Acuáticos (LIRA) of the Instituto Tecnológico de Boca del Río (ITBOCA), where fish were dissected to extract muscle tissue from each organism. Once the samples were extracted, they were stored in airtight polyethylene bags and then frozen at $-14^{\circ} \mathrm{C}$. They were then subjected to a freeze-drying dehydration process using the Thermo Savant Modulyo D-115 for $72 \mathrm{~h}$ at $-49^{\circ} \mathrm{C}$ and a vacuum pressure of $36 \times 10^{-3} \mathrm{mbar}$. After this process, the samples were stored in sealed bags and finally ground in a blender to a fine particle size. Subsequently, the samples were stored in a desiccator until further processing.

\subsection{Analytical Preparation and Microwave Acid Digestion}

The material used in the development of the metal analysis was prepared according to the specifications for metal analysis NOM-117-SSA1-1994 [27]. The laboratory material was washed with phosphate-free neutral Extran ${ }^{\circledR}$ soap for $24 \mathrm{~h}$ and then rinsed with tap water. The material was then placed in a solution of distilled water with $20 \%$ nitric acid $\mathrm{HNO}_{3}\left(\right.$ J.T.Baker $\left.{ }^{\circledR}\right)$ for $24 \mathrm{~h}$. After this period, the material was rinsed again with tap water. At the end, the material was washed with deionised water (Milli-Q) for $24 \mathrm{~h}$, and finally dried and stored until use.

Sample digestion was carried out with a CEM Mars 5 microwave oven (CEM Corporation, Mathews, NC, USA) using $0.5 \mathrm{~g}$ of previously freeze-dried and ground sample. To this sample, $9 \mathrm{~mL}$ of reagent grade $\mathrm{HNO}_{3}$ was added, and a pressure of 120 and 100 PSI was used for the microwave digestion, with a temperature of 150 and $190^{\circ} \mathrm{C}$ for 5 and $10 \mathrm{~min}$, respectively. A blank sample and a positive control were run throughout the sample analysis. After completion of the microwave digestion, $0.45 \mu \mathrm{m}$ Millipore ${ }^{\circledR}$ nitrocellulose filters were used and the filtrate was made up to $25 \mathrm{~mL}$ with deionised water (Milli-Q), the final extract was placed in an amber polyethylene vial and stored at $4{ }^{\circ} \mathrm{C}$.

\subsection{Quantification of Metals}

A Thermo Scientific Ice 3500 AA atomic absorption apparatus (Thermo Scientific ${ }^{\circledR}$, Beijing, China) was used to identify and quantify the concentration of metals by flame spectrophotometry. The procedure was performed according to the operating specifications established by the manufacturer and NOM-117-SSA1-1994 [27].

A calibration curve was prepared for each of the metals using certified high-purity standards (High-Purity Standards, Charleston, SC, USA), to quantify the metals in $\mu \mathrm{g} \mathrm{g}^{-1}$ (dry weight). This curve presented an adequate fit, obtaining a correlation coefficient higher than 0.99 .

\subsection{Statistical Analysis}

Metal concentrations in muscle tissue of native and invasive fish were analysed by site, season and species with TIBCO Statistica 14.0.0.15 software (TIBCO Software Inc., Palo Alto, CA, USA), using a one-way ANOVA. Metal data from invasive fish species samples were transformed using natural logarithms to meet the ANOVA assumptions. A multiple comparison of means was then performed using the Tukey's test to determine the statistical differences $(p<0.05)$ between metal concentration at the sampling sites, season, and different native and invasive fish species. 


\section{Results}

\subsection{Metal Concentrations in Invasive Species}

The Cd concentrations obtained in muscle tissue of the invasive species were higher than those obtained for the metal $\mathrm{Pb}$ in these species. The LCAR and LLAR sites had the highest $\mathrm{Cd}$ concentrations in the tissue of the four invasive fish species analysed: Amazon sailfin catfish (AS); grass carp (GC); common carp (CC); and Nile tilapia (NT) (Table 1). The lowest $\mathrm{Cd}$ concentration was detected in S9, located in the middle part of the fluviallagoon-deltaic system of the Palizada River. Cd concentrations in muscle tissue of the invasive species did not show statistically significant differences between the sampling sites analysed individually $(p>0.05)$ (Figure 2$)$.

Table 1. Metal concentration (mean \pm standard deviation) in fish muscle tissue ( $\mu \mathrm{g} \mathrm{g}^{-1}$ dry weight) of invasive and native fish species by sampling site in the fluvial-lagoon-deltaic system of the Palizada River, Campeche.

\begin{tabular}{|c|c|c|c|}
\hline \multicolumn{4}{|c|}{ Invasive fish species } \\
\hline Sampling site & $\mathbf{N}$ & $\mathrm{Cd}$ & $\mathbf{P b}$ \\
\hline S1 & 3 & $5.593 \pm 1.245$ & $4.670 \pm 0.603$ \\
\hline S2 & 5 & $5.682 \pm 0.880$ & $5.290 \pm 0.803$ \\
\hline S3 & 2 & $6.065 \pm 0.403$ & $5.340 \pm 0.000$ \\
\hline S4 & 3 & $6.960 \pm 0.533$ & $6.080 \pm 0.640$ \\
\hline S5 & 2 & $6.820 \pm 0.098$ & $5.510 \pm 0.226$ \\
\hline S6 & 3 & $5.993 \pm 0.340$ & $5.480 \pm 0.370$ \\
\hline S7 & 2 & $6.500 \pm 0.070$ & $6.160 \pm 0.410$ \\
\hline LCOR & 5 & $6.328 \pm 1.027$ & $5.374 \pm 0.725$ \\
\hline S8 & 3 & $7.210 \pm 0.704$ & $6.680 \pm 0.302$ \\
\hline S9 & 3 & $5.403 \pm 0.370$ & $5.070 \pm 0.480$ \\
\hline LCOL & 2 & $5.975 \pm 1.053$ & $5.590 \pm 1.456$ \\
\hline S10 & 3 & $6.053 \pm 1.317$ & $5.243 \pm 0.998$ \\
\hline LDUL2 & 3 & $6.693 \pm 0.821$ & $5.516 \pm 0.858$ \\
\hline LCAR & 1 & 7.870 & 2.320 \\
\hline S11 & 2 & $7.155 \pm 0.261$ & $6.355 \pm 0.601$ \\
\hline LLAR & 1 & 7.660 & 7.760 \\
\hline LCRU & 1 & 6.890 & 6.450 \\
\hline TOTAL & 44 & $6.345 \pm 0.917$ & $5.545 \pm 0.965$ \\
\hline \multicolumn{4}{|c|}{ Native fish species } \\
\hline Sampling site & $\mathbf{N}$ & Cd & $\mathbf{P b}$ \\
\hline S2 & 1 & 5.340 & 4.560 \\
\hline LFRE & 1 & 3.450 & 4.340 \\
\hline LDUL & 3 & $5.523 \pm 0.356$ & $4.896 \pm 0.825$ \\
\hline LCOL & 1 & 4.900 & 4.560 \\
\hline LCAR & 1 & 5.840 & 5.540 \\
\hline Total & 7 & $5.157 \pm 0.830$ & $4.812 \pm 0.614$ \\
\hline
\end{tabular}

Abbreviations: LCOR: Laguna Corcho; LDUL: Laguna Dulce; LDUL2: Laguna Dulce 2; LCAR: Laguna Carmen; LLAR: Laguna Larga; LCOL: Laguna Colorada; LCRU: Laguna de las Cruces; LFRE: Laguna Frente.

$\mathrm{Pb}$ concentrations showed statistically significant differences $(p<0.05)$ between the LLAR and LCAR sampling sites, while the rest of the sites analysed showed a similar pattern in the detected concentrations (Figure 2). LCAR showed the highest concentration of $\mathrm{Cd}$, but the lowest concentration of $\mathrm{Pb}$ was also detected at this site (Table 1).

The concentrations for $\mathrm{Cd}$ and $\mathrm{Pb}$ did not show statistically significant differences between seasons $(p>0.05)$. Cd registered the highest concentration during the rainy season with $6.551 \pm 1.014$, followed by the dry season with $6.538 \pm 0.639$, while the lowest concentration was found during the north winds season with $5.998 \pm 1.003 \mu \mathrm{g} \mathrm{g}^{-1}$ (dry weight). Cd presented the highest concentration in the invasive species analysed with respect to $\mathrm{Pb}$ concentrations, being the highest concentration in the dry season with $5.864 \pm 0.547$ followed by the north winds season with $5.504 \pm 0.764$ contrasting with 
the rainy season which presented the lowest concentration with $5.226 \pm 1.421 \mu \mathrm{g} \mathrm{g}^{-1}$ dry weight.

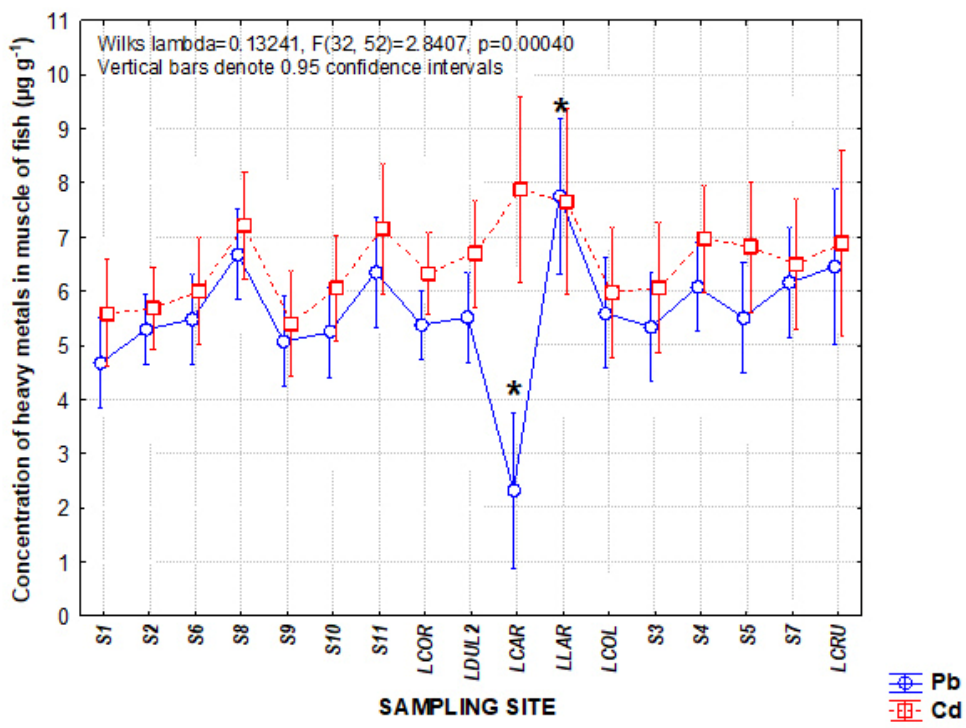

Figure 2. Metal concentration in muscle tissue ( $\mu \mathrm{g} \mathrm{g}^{-1}$ dry weight) of invasive fish species by sampling site in the fluvial-lagoon-deltaic system of the Palizada River, Campeche. ${ }^{*}$ indicate statistically significant differences $(p<0.05)$ of metals between sampling sites. Abbreviations: LCOR: Laguna Corcho; LDUL: Laguna Dulce; LDUL2: Laguna Dulce 2; LCAR: Laguna Carmen; LLAR: Laguna Larga; LCOL: Laguna Colorada; LCRU: Laguna de las Cruces; LFRE: Laguna Frente.

The invasive fish species common carp (CC) and Amazon sailfin catfish (AS) showed the highest concentrations of $\mathrm{Cd}$ and $\mathrm{Pb}$ (Figure 3), the latter being lower than those obtained for $\mathrm{Cd}$ in the same species. However, statistically significant differences in $\mathrm{Cd}$ $(p<0.05)$ were detected between Amazon sailfin catfish (AS) and Nile tilapia (NT), the latter species having the lowest $\mathrm{Cd}$ and $\mathrm{Pb}$ concentrations in relation to the rest of the invasive fish species (Table 2). There were no statistically significant differences $(p>0.05)$ between $\mathrm{Pb}$ concentrations in the four invasive fish species analysed.

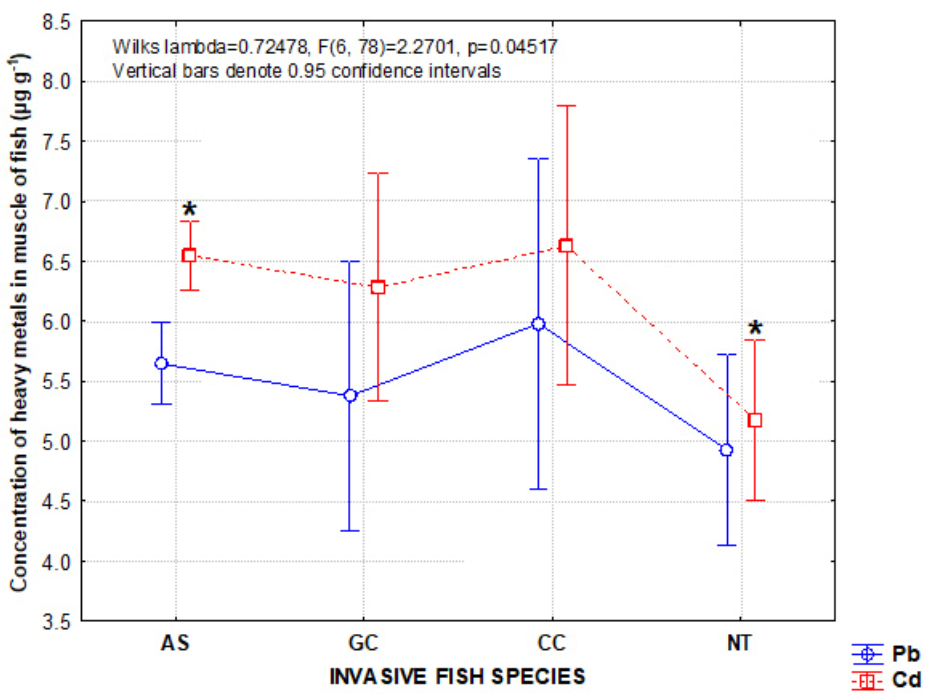

Figure 3. Metal concentration in muscle tissue ( $\mu \mathrm{g} \mathrm{g}^{-1}$, dry weight) of invasive fish species in the fluvial-lagoon-deltaic system of the Palizada River, Campeche. Abbreviations: AS: Amazon sailfin catfish; GC: grass carp; CC: common carp; NT: Nile tilapia. * indicate statistically significant differences $(p<0.05)$ between fish species. 
Table 2. Metal concentration in muscle tissue ( $\mu \mathrm{g} \mathrm{g}^{-1}$, dry weight) of native and invasive fish species in the fluvial-lagoondeltaic system of the Palizada River, Campeche.

\begin{tabular}{cccccccc}
\hline & \multicolumn{2}{l}{ Invasive Species } & \multicolumn{3}{c}{ Native Species } \\
\hline Species Code & $\mathbf{N}$ & $\mathbf{P b}$ & $\mathbf{C d}$ & Species Code & $\mathbf{N}$ & $\mathbf{P b}$ & $\mathbf{C d}$ \\
\hline AS & 33 & $5.645 \pm 1.047$ & $6.547 \pm 0.873$ & TC & 2 & $5.080 \pm 1.046$ & $4.685 \pm 1.746$ \\
GC & 3 & $5.376 \pm 0.063$ & $6.283 \pm 0.453$ & BS & 2 & $4.885 \pm 0.926$ & $5.535 \pm 0.431$ \\
CC & 2 & $5.980 \pm 0.905$ & $6.630 \pm 0.127$ & MC & 3 & $4.586 \pm 0.046$ & $5.220 \pm 0.280$ \\
NT & 6 & $4.930 \pm 0.464$ & $5.173 \pm 0.565$ & & & & \\
Total & 44 & $5.545 \pm 0.965$ & $6.345 \pm 0.917$ & Total & 7 & $4.812 \pm 0.614$ & $5.157 \pm 0.830$ \\
\hline
\end{tabular}

Abbreviations: N: number of organisms; Invasive species of fish: AS: Amazon sailfin catfish Pterygoplichthys pardalis; GC: Grass carp Ctenopharyngodon idealla; CC: Common carp Cyprinus carpio; NT: Nile tilapia Oreochromis niloticus; Native species of fish: TC: Twoband cichlid Vieja bifasciata; MC: Mayan cichlid Mayaheros urophthalmus; BS: Bay snook Petenia splendida.

\subsection{Metal Concentration in Native Species}

The collection of native fish species in the fluvial-lagoon-deltaic system of the Palizada River was a small number compared to the number of invasive fish collected at the sampling sites. These fish were collected during the three seasons and only a total of seven fish were obtained at some of the sampling sites.

LCAR showed the highest concentrations of $\mathrm{Cd}$ and $\mathrm{Pb}$, followed by LDUL which showed the same pattern for both metals. Pb presented a higher concentration than $\mathrm{Cd}$ only at LFRE, in the rest of the sampling sites analysed the mean concentrations of $\mathrm{Cd}$ were higher than those obtained for $\mathrm{Pb}$ (Table 1).

The rainy season presented the highest concentration of $\mathrm{Cd}$ with 5.920 and $\mathrm{Pb}$ with 5.820 , followed by the dry season with $5.360 \pm 0.470$ for $\mathrm{Cd}$ and $\mathrm{Pb}$ with $4.886 \pm 0.565 \mu \mathrm{g} \mathrm{g}^{-1}$ (dry weight). The lowest concentration was detected in northeast with $4.700 \pm 1.086$ for $\mathrm{Cd}$ and $4.403 \pm 0.212 \mu \mathrm{g} \mathrm{g}^{-1}$ (dry weight) for Pb. Bay snook (BS) had the highest concentration of Cd, followed by Mayan cichlid (MC). While the Twoband cichlid (TC) species showed the highest mean $\mathrm{Pb}$ concentration and the lowest $\mathrm{Cd}$ concentration (Table 2).

\section{Discussion}

\subsection{Concentration of Metals in Invasive Species}

The accumulation of $\mathrm{Cd}$ and $\mathrm{Pb}$ in the four invasive fish species, at all sampling sites and seasons, indicates the capacity of these species to bioaccumulate these elements in their muscle tissue. The bioaccumulation of metals in tissues and fatty organs of aquatic organisms is influenced by their diet, making fish more exposed to chronic risk than other benthic aquatic species, such as crustaceans or mollusks [28,29].

The differences detected in $\mathrm{Cd}$ and $\mathrm{Pb}$ concentrations at sampling sites such as LCAR may be associated with its location at the end position, where it receives the pollutant transport from the discharge area of the fluvial-lagoon system, which flows into the coastal Laguna de Términos and this, in turn, into the Gulf of Mexico. The resuspension of sediments in the water column and the contribution of pollutants through the tributaries to the fluvial-lagoon-deltaic system of the Palizada River are other causes that contribute metals to this system, such as the Grijalva-Usumacinta basin, which is impacted by different anthropogenic sources. The Palizada River system receives wastewater discharges from urban settlements and thus pollutants along its course, which are discharged into this system without any treatment $[24,28,29]$.

Analysis of fish muscle tissue is a monitoring tool that helps to determine whether there is a transfer of metals and other pollutants from the habitat to the tissue of the organisms. Consumption of impacted organisms can have a potential harmful effect on public health through the consumption of fish in its traditional forms, whether fried, processed as protein concentrate, silage, and/or processed as fishmeal [26,30]. The accumulation of metals varies according to different factors such as the type of species, size, type of feed, environmental conditions, level of contamination at the fishing site, physiological 
characteristics of the fish [30], and the period of exposure to which an organism is subjected in polluted waters $[28,31]$.

This is the first study to analyse the concentrations of metals such as $\mathrm{Cd}$ and $\mathrm{Pb}$ in native and invasive fish species in the Palizada River. Previous research has been related to biological aspects and socio-economic impact caused by invasive species in this area $[16,23,24]$, in addition to the determination of metals in meadow grasses [29]. For this reason, we mainly used the comparison between research generated with native and invasive fish species in other regions of the world, taking into account that this information helps to explain the pattern of metals in the species analysed in the context of the study area.

The maximum accumulation of $\mathrm{Cd}$ in the muscle tissue of the invasive fish in this study occurred during the rainy and dry seasons. These results may be related to the fact that, during the rainy season, the mobilisation of sediments according to climatic conditions and fertilisers derived from agricultural activity in the basin is the main source of this element [28-30]. On the other hand, during the the dry season, the reduction of the water column level is very marked, which concentrates pollutants in the sediments, making them the pathway that transfers of metals to the aquatic biota [30-32].

The maximum concentration of $\mathrm{Cd}$ and $\mathrm{Pb}$ was obtained in muscle tissue of common carp (CC) and Amazon sailfin catfish (AS). The influence of fish feeding habits is noteworthy, whereby diet is considered to be the main pathway of metal bioaccumulation [31,33]. This may reveal that the maximum concentrations detected in common carp (CC) and Amazon sailfin catfish (AS) show a similar trend, as both belong to the omnivore group and only the former can also feed on plankton and algae [31]. The similarity in feeding habits explain in part the tendency to accumulate metals in their muscle tissue. The concentrations of metals obtained in Amazon sailfin catfish (AS) in this research were higher than those obtained in other areas of the Grijalva and Usumacinta River basin [21,34], as well as those reported in other regions of the world, in different invasive species such of the genus Pterygoplichthys such as P. pardalis and P. multiradiatus [35-38]. It should be noted that there is a need to establish an international standard of permissible limit for metals in order to regulate exposure from consumption of these species.

The Nile tilapia O. niloticus is also of economic importance throughout Mexico, although its presence in ecosystems such as the fluvial-lagoon-deltaic system of the Palizada River is an indicator of ecological disturbance. This is due to the predatory capacity of this species [31] with the bioaccumulation of metals in its muscle tissue showing its capacity to accumulate environmental pollutants [35-39]. The concentrations obtained in this research in O. niloticus muscle were higher than those reported in other research works on species such as O. mossambicus [39] and O. niloticus [40]. Exploitation of these species should consider their capacity to bioaccumulate pollutants such as metals, as they could pose a risk to public health. The main strategy to control invasive species is through regional harvesting programmes. By integrating them as part of the diet, their consumption is intended to achieve control of invasive species and protection of native species in the areas of entry of these species.

Both $\mathrm{Cd}$ and $\mathrm{Pb}$, analysed in this research in fish muscle tissue, have an impact on public health. Since $\mathrm{Pb}$ is a non-essential element, its exposure is widely documented to cause neurotoxic and nephrotoxic effects, while inorganic $\mathrm{Pb}$ is considered a possible carcinogen in humans [33,40]. Furthermore, $\mathrm{Cd}$ has important health effects as an endocrine disruptor, which can cause prostate damage [41]. Exposure to $\mathrm{Cd}$ in humans and wildlife can cause damage to the kidneys, intestinal tract, reproductive system and cardiovascular system. It is also classified as a carcinogen by the International Agency for Research on Cancer (IARC) [39,41,42]. The negative effects of $\mathrm{Cd}$ and $\mathrm{Pb}$ on public health and aquatic fauna highlight the importance of assessing these heavy metals as indicators of environmental quality in aquatic ecosystems.

The concentrations of $\mathrm{Cd}$ and $\mathrm{Pb}$ in invasive fish in the fluvial-lagoon system of the Palizada river exceeded the maximum tolerable limit (MTL) for fishery products. The maximum levels of $\mathrm{Cd}$ and $\mathrm{Pb}$ established by European Union (EU) are 0.05 and $0.3 \mu \mathrm{g} \mathrm{g}^{-1}$, 
respectively [43]. On the other hand, the maximum limits in Mexico, according to the Diario Oficial (2009), are $0.5 \mathrm{\mu g} \mathrm{g}^{-1}$ for $\mathrm{Cd}$ and $\mathrm{Pb}$ in the edible part of the muscle, in fresh, chilled and frozen products such as fish [44]. The United States Food and Drug Administration (USFDA) concurred on the latter permissible limit set for Cd [45]. Meanwhile, the European Union, the USFDA and the Standardisasi Nasional Indonesia (SNI) set a standard permissible limit for $\mathrm{Pb}$ of $0.3 \mu \mathrm{g} \mathrm{g}^{-1}[43,46,47]$. On the other hand, the World Health Organization (WHO) considered a maximum permissible limit of $2.00 \mathrm{\mu g} \mathrm{g}^{-1}$ for $\mathrm{Pb}$ [48].

Discrepancies between the permissible limits set by international bodies may underestimate or overestimate the risk of dietary exposure to heavy metals for populations living in southeastern Mexico. The provisional tolerable daily intake (PTDI) for Cd has a value of $58.3 \mu \mathrm{g}$ per person ${ }^{-1}$ [49]; while the individual tolerable daily intake (ITDI) in fish muscle ranges from $0.27-0.41 \mathrm{~kg}$ (wet weight) [33]. For Pb, the EU, in 2006, considered a limit value of $1.50 \mu^{-1} \mathrm{~g}^{-1}$ per week [43]. The concentrations obtained in the invasive fish of the Palizada River system in this research exceeded the national and international permitted limits. It should be noted that the maximum concentrations of $\mathrm{Cd}$ and $\mathrm{Pb}$ were detected in invasive species of major consumption and commercial importance such as common carp (CC) and Amazon sailfish (AS), which increases the potential risk of exposure of consumers of these species to pollutants such as metals.

\subsection{Concentration of Metals in Native Species}

Native fish species showed lower concentrations of $\mathrm{Cd}$ and $\mathrm{Pb}$ compared to the maximum values obtained for invasive fish species (Table 2). These results indicate the availability of these elements in the environment, but also that native species are well adapted to their environment, as they have metabolic pathways [31,40], which allow them to accumulate a lower concentration of $\mathrm{Cd}$ and $\mathrm{Pb}$, compared to invasive species that have recently entered the ecosystem. Maximum $\mathrm{Cd}$ and $\mathrm{Pb}$ concentrations per sampling site showed similar trends to those obtained for invasive fish species. This indicates that both species are exposed throughout the year to these metals.

Due to the lack of scientific information on the concentration of metals such as $\mathrm{Pb}$ and $\mathrm{Cd}$ in fish species native to the study area, reference is made to the reported concentration of these metals in the Mugil cephalus, an economically important and commonly consumed species [33]. Furthermore, this species inhabits ecosystems similar to the study area analysed in this research. The levels of metals detected in M. cephalus were lower than those obtained in the native species of the Palizada River system, indicating a greater availability in the study area and a greater capacity for accumulation in the species studied.

The native fish species, Bay snook (BS) and Mayan cichlid (MC), showed the same pattern as the invasive species of bioaccumulating a higher concentration of $\mathrm{Cd}$ compared to $\mathrm{Pb}$. Only the Twoband cichlid (TC) species did not show the same pattern, with $\mathrm{Pb}$ showing a higher mean concentration with respect to $\mathrm{Cd}$. The concentrations obtained for $\mathrm{Cd}$ and $\mathrm{Pb}$ in native fish species in the fluvial-lagoon system of the Palizada River provide a scientific contribution on the concentration of metals in native species, particularly because the concentrations exceed the permissible limits. The results obtained for $\mathrm{Cd}$ and $\mathrm{Pb}$ suggest a potential chronic effect on the population that consumes these native and invasive fish species in the study area, representing a potential risk to public health and the environment.

\section{Conclusions}

The presence of $\mathrm{Cd}$ and $\mathrm{Pb}$ in the muscle tissue of native and invasive fish is an indicator of the environmental exposure of the ecosystem in which these fish develop. The concentrations identified in this study are associated with the physiological characteristics of the fish analysed.

The concentrations obtained in the fish species with respect to the sampling sites are related to sediment entrainment and to the hydrodynamics of the ecosystem, which allows for an increased exchange of currents, and in doing so, modifies the fish habitat in the study 
area. These concentrations may indicate the bioavailability of these metals by terrigenous and anthropogenic inputs, which has a negative impact on native and invasive fish living in the lagoon-deltaic system of the Palizada River.

In this study, the highest $\mathrm{Cd}$ concentration is reported for the common carp, an invasive species of high consumption. It is important to mention that there are governmental programmes that promote its consumption as a control and eradication strategy, in order to protect native species in the Gulf of Mexico ecosystems.

There is no record of studies demonstrating the food safety of fish in this area, however, there are studies that report that consumption of fishery resources contaminated by metals can influence androgenic activities and cause possible chronic effects on public health.

Specific national legislation on permissible limits for metals in invasive species is required, which would undoubtedly imply the need to strengthen scientific knowledge through research, disseminate the results and raise public awareness of the risks of consumption. Therefore, supervision and control of compliance with environmental legislation must be generated in order to act in the control of anthropogenic sources for the improvement and quality of the ecosystem.

Author Contributions: Conceptualization, M.d.R.C.-C. and A.T.W.-K.; methodology, G.N.-R.; validation, M.d.R.C.-C. and A.T.W.-K.; investigation, M.d.R.C.-C. and F.L.-R.; resources, M.d.R.C.-C. and F.L.-R.; writing—original draft preparation, M.d.R.C.-C., A.T.W.-K. and G.N.-R.; writing—review and editing, M.d.R.C.-C., G.N.-R., A.T.W.-K.; supervision, F.L.-R., A.T.W.-K.; project administration, M.d.R.C.-C. and F.L.-R. All authors have read and agreed to the published version of the manuscript.

Funding: To the Tecnológico Nacional de México/Instituto Tecnológico de Boca del Río (TecnM/ ITBOCA), and CONACYT (Consejo Nacional de Ciencia y Tecnología) for the support granted to execute this work to Scholarship No. 740232, through Postdoctoral Stays linked to the Strengthening of the Quality of the National Postgraduate, CALL 2018 (1).

Institutional Review Board Statement: The handling of specimens in this research was conducted in accordance with the Code of Practice for the Housing and Care of Animals used in scientific procedures. This document was issued on 14 April 2016 and under Section 1 of the Animals (Scientific Procedures) Act. The project identification code 5290.19-P for this paper, approval date from January 2018 to the current date by the Institutional Postgraduate and Research Committee, Instituto Tecnológico de Boca del Río (ITBOCA).

Data Availability Statement: We choose to exclude this statement.

Acknowledgments: To the Tecnológico Nacional de México/Instituto Tecnológico de Boca del Río (TecnM/ITBOCA) for facilitating the development of this project. Also, to the Instituto Nacional de Pesca y Acuacultura for the partial funding through the research project "Aspectos biológicos pesqueros del pez diablo Pterygoplychthys pardalis en el Rio Palizada" (Biological aspects of the Amazon sailfin catfish Pterygoplychthys pardalis in the Palizada River).

Conflicts of Interest: The authors declare no conflict of interest.

\section{References}

1. Londoño-Franco, L.F.; Londoño-Muñoz, P.T.; Muñoz-García, F.G. Los riesgos de los metales pesados en la salud humana y animal. Biotecnol. Sect. Agropecu. Agroind. 2016, 14, 145-153.

2. Annabi, A.; Saïd, K.; Messaoudi, I. Heavy metal levels in gonad and liver tissues-effects on the reproductive parameters of natural populations of Aphanius facsiatus. Environ. Sci. Pollut. Res. Int. 2013, 20, 7309-7319. [CrossRef]

3. Páez-Osuna, F.; Osuna-Martínez, C.C. Bioavailability of cadmium, copper, mercury, lead, and zinc in subtropical coastal lagoons from the Southeast Gulf of California using mangrove oysters (Crassostrea corteziensis and Crassostrea palmula). Arch. Environ. Contam Toxicol. 2015, 68, 305-316. [CrossRef]

4. Castañeda-Chávez, M.R.; Navarrete-Rodríguez, G.; Lango-Reynoso, F.; Galaviz-Villa, I.; Landeros-Sánchez, C. Heavy Metals in Oysters, Shrimps and Crabs from Lagoon Systems in the Southern Gulf of México. J. Agric. Sci. 2014, 6, 108-117. [CrossRef]

5. Castañeda-Chávez, M.R.; Lango-Reynoso, F.; Navarrete-Rodríguez, G. Heavy Metals in Sediment from Alvarado Lagoon System in Veracruz, México. Intern. J. Environ. Agric. Biotechnol. 2017, 2, 1209-1214. [CrossRef]

6. Góngora-Gómez, A.M.; García-Ulloa, M.; Muñoz-Sevilla, N.P.; Domínguez-Orozco, A.L.; Villanueva-Fonseca, B.P.; Hernández-Sepúlveda, J.A.; Ortega Izaguirre, R. Heavy-metal contents in oysters (Crassostrea gigas) cultivated on the southeastern coast of the Gulf of California, Mexico. Hidrobiológica 2017, 27, 219-227. [CrossRef] 
7. Góngora-Gómez, A.M.; García-Ulloa, M.; Villanueva-Fonseca, B.P.; Domínguez-Orozco, A.L.; Hernández-Sepúlveda, J.A. Concentraciones de cobre y zinc en el ostión Crassostrea gigas cultivado en dos lagunas costeras del norte de Sinaloa, México. Adv. Investig. Agropecu. 2017, 21, 19-29.

8. Góngora-Gómez, A.M.; Domínguez-Orozco, A.L.; Villanueva-Fonseca, B.P.; Muñoz-Sevilla, N.P.; García-Ulloa, M. Seasonal levels of heavy metals in soft tissue and muscle of the pen shell Atrina maura (sowerby, 1835) (Bivalvia: Pinnidae) from a farm in the southeastern coast of the Gulf of California, Mexico. Rev. Inter. Contam. Ambie 2018, 34, 57-68. [CrossRef]

9. Frías-Espericueta, M.G.; Aguilar-Juárez, M.; Osuna-López, I.; Abad-Rosales, S.; Izaguirre-Fierro, G.; Voltolina, D. Los metales y la camaronicultura en México. Hidrobiológica 2011, 21, 217-228.

10. Lango-Reynoso, F.; Castañeda-Chávez, M.R.; Landeros-Sánchez, C.; Galavíz-Villa, I.; Navarrete-Rodríguez, G.; Soto-Estrada, A. $\mathrm{Cd}, \mathrm{Cu}, \mathrm{Hg} \mathrm{AND} \mathrm{Pb}$, and organochlorines pesticides in commercially important benthic organisms coastal lagoons SW Gulf of Mexico. Agric. Sci. 2013, 1, 63-80. [CrossRef]

11. Páez-Osuna, F.; Osuna-Martínez, C.C. Biomonitores de la contaminación costera con referencia a las costas mexicanas: Una revisión sobre los organismos utilizados. Hidrobiológica 2011, 21, 229-238.

12. Yancheva, V.; Velcheva, I.; Stoyanova, S.; Georgieva, E. Fish in Ecotoxicological Studies. Ecol. Balk. 2015, 7, 149-169.

13. Velázquez-Velázquez, E.; Vega-Cendejas, M.E. Los peces como indicadores del estado de salud de los ecosistemas acuáticos. CONABIO. Biodiversitas 2004, 57, 12-15.

14. del Ángel, L.E.A.; Wakida Kusunoki, A.T.; Guevara-Carrió, E.C.; Brito Pérez, R.; Cabrera-Rodríguez, P. Peces invasores de agua dulce en la región de la laguna de Términos, Campeche. Unacar Tecnociencia 2009, 3, 11-28.

15. Amador-del Ángel, L.E.; Wakida-Kusunoki, A.T. Peces invasores en el sureste de México. In Especies Acuáticas Invasoras en México; Mendoza, R., Koleff, P., Coords, D.F., Eds.; Comisión Nacional para el Conocimiento y Uso de la Biodiversidad: Campeche, Mexico, 2014; pp. 425-433.

16. del Ángel, L.E.A.; Guevara-Carrió, E.C.; Brito Pérez, R.; Endañú-Huerta, E. Aspectos Biológicos e Impacto Socio-Económico de los Plecos del Género Pterygoplichthys y dos Cíclidos no Nativos en el Sistema Fluvio Lagunar Deltaico Río Palizada, en el Área Natural Protegida Laguna de Términos, Campeche; Informe final SNIB-CONABIO. Ficha técnica tilapia Oreochromls niloticus, proyecto No. GN004; Universidad Autónoma del Carmen, Centro de Investigación de Ciencias Ambientales, Facultad de Ciencias Naturales: Campeche, Mexico, 2014.

17. Mendoza, R.; Contreras, S.; Ramírez, C.; Koleff, P.; Álvarez, P.; Aguilar, V. Los peces diablo: Especies invasoras de alto impacto. CONABIO. Biodiversitas 2007, 70, 1-5.

18. Mendoza, R.; Alfaro, E.; Cudmore, B.; Orr, R.; Fisher, J.P.; Contreras-Balderas, S.; Courtenay, W.R.; Koleff-Osorio, P.; Mandrak, N.; Álvarez-Torres, P.; et al. Trinational Risk Assessment Guidelines for Aquatic Alien Invasive Species. Test Cases for the Snakeheads (Channidae) and Armored Catfishes (Loricariidae) in North American Inland Waters; Commission for Environmental Cooperation Montreal: Quebec, QC, Canada, 2009.

19. SAGARPA. Promueve CONAPESCA Consumo de Nuevas Especies y su Aprovechamiento Productivo. Comunicado de Prensa Num.601/11. 2011. Available online: http://www.sagarpa.gob.mx/saladeprensa/boletines2/2011/octubre/Documents/2011 B601.pdf (accessed on 22 March 2021).

20. Diario Oficial. Norma Oficial Mexicana. NOM-060-SAG/PESC-2016. Pesca Responsable en Cuerpos de Aguas Continentales Dulceacuícolas de Jurisdicción Federal de los Estados Unidos Mexicanos. Especificaciones Para el Aprovechamiento de los Recursos Pesqueros. 2016. Available online: http:/ / www.dof.gob.mx/nota_detalle.php?codigo=5452927\&fecha=19/09/2016 (accessed on 22 January 2021).

21. Lorenzo-Márquez, H.; Torres-Dosal, A.; Barba-Macías, E.; Ilizaliturri HErnández, C.A.; Martínez-Salinas, R.I.; Morales López, J.J.; Sánchez-Moreno, I. Estimación de riesgo de exposición a metales pesados por consumo de plecos (Pterygoplichthys spp.) en infantes de comunidades ribereñas de los ríos Grijalva y Usumacinta, México. Rev. Int. Contam. Ambie 2016, 32, 153-164. [CrossRef]

22. Villalobos-Zapata, G.J.; Mendoza-Vega, J. La Biodiversidad en Campeche: Estudio de Estado; Comisión Nacional para el Conocim22iento y Uso de la Biodiversidad (CONABIO), Gobierno del Estado de Campeche, Universidad Autónoma de Campeche, El Colegio de la Frontera Sur: Campeche, Mexico, 2010; p. 730.

23. Wakida-Kusunoki, A.T.; del Ángel, L.E.A. Aspectos biológicos del pleco invasor Pterygoplichthys pardalis (Teleostei: Loricariidae) en el río Palizada, Campeche, México. Rev. Mex. Biodiv 2011, 82, 870-878. [CrossRef]

24. Agraz Hernández, C.M.; Osti Sáenz, J.; Chan Keb, C.; Arriaga Martínez, V.; Acosta Velázquez, J.; Castillo Domínguez, S.; Gómez Ramírez, D.; Reyes-Castellanos, J.; Conde Medina, P.; Martínez Kumul, J. Grado de conservación del ecosistema de mangle en la laguna de Términos, Campeche. Propuesta de políticas ambientales y acciones de restauración. In Aspectos Socioambientales de la Región de la Laguna de Términos, Campeche; Ramos-Miranda, J., Villalobos-Zapata, G.J., Eds.; EPOMEX, Universidad Autónoma de Campeche: Campeche, Mexico, 2015; pp. 117-132.

25. Miller, R.R.; Minckley, W.L.; Norris, S.M. Peces Dulceacuícolas de México; Conabio, Simac, Ecosur: Campeche, Mexico, 2009; 559p.

26. Wakida Kusunoki, A.T.; del Ángel, L.E.A. Nuevos registros de los plecos Pterygoplichthys pardalis (Castelnau, 1855) y P. disjunctivus (Weber, 1991) (Siluriformes: Loricariidae) en el Sureste de México. Hidrobiológica 2008, 18, 251-258.

27. Diario Oficial, Norma Oficial Mexicana NOM-117-SSA1-1994. Bienes y servicios. método de prueba para la determinación de cadmio, arsénico, plomo, estaño, cobre, fierro, zinc y mercurio en alimentos, agua potable y agua purificada por espectrometría de absorción atómica. Diario Oficial de la Federación, 16 August 1995. 
28. Nakayama, S.M.; Ikenaka, Y.; Muzandu, K.; Choongo, K.; Oroszlany, B.; Teraoka, H.; Ishizuka, M. Heavy metal accumulation in lake sediments, fish (Oreochromis niloticus and Serranochromis thumbergi), and crayfish (Cherax quadricarinatus) in Lake Itezhi-tezhi and Lake Kariba, Zambia. Arch. Environ. Contam Toxicol 2010, 59, 291-300. [CrossRef] [PubMed]

29. Botello, V.A.; Villanueva, S.; Martínez, E. Metales y metaloides en praderas de pastos marinos de la laguna de Términos, Campeche. In Aspectos Socioambientales de la Región de la Laguna de Términos, Campeche; Ramos-Miranda, J., Villalobos-Zapata, G.J., Eds.; Universidad Autónoma de Campeche: Campeche, Mexico, 2015; pp. 133-143.

30. Akoto, O.; Bismark-Eshun, F.; Darko, G.; Adei, E. Concentrations and Health Risk Assessments of Heavy Metals in Fish from the Fosu Lagoon. Int. J. Environ. Res. 2014, 8, 403-410.

31. Zuluaga-Rodríguez, J.; Gallego-Ríos, S.E.; Ramírez-Botero, C.M. Content of $\mathrm{Hg}, \mathrm{Cd}, \mathrm{Pb}$ and As in fish species: A review. VITAE Rev. Fac. Cienc. Farm. Aliment. 2015, 22, 148-159. [CrossRef]

32. Loganathan, P.; Hedley, M.J.; Grace, N.D. Pasture soils contaminated with fertilizer-derived cadmium and fluorine: Livestock effects. Rev. Environ. Contamin Toxicol. 2008, 192, 29-66.

33. Frías-Espericueta, M.G.; Zamora-Sarabia, F.K.G.; Osuna-López, J.I.; Muy-Rangel, M.D.; Rubio-Carrasco, W.; Aguilar-Juárez, M.; Voltolina, D. Cadmium, Copper, Lead, and Zinc Contents of Fish Marketed in NW Mexico. Sci. World J. 2014, 1, 1-4. [CrossRef]

34. Maldonado-Enríquez, E.J.; López-Noverola, U.; Salinas-Hernández, R.M.; González-Cortés, N.; Cuenca-Soria, C.A.; Jiménez-Vera, R.; Hernández-Juárez, J.L. Contenido de metales pesados en músculo de pez diablo Pterygoplichthys pardalis. ReIbCi 2015, 2, 67-73.

35. Ernawati, Y. The analysis of the concentration of heavy metals cadmium, mercury and lead in the flesh of suckermouth catfish (Pterygoplichthys pardalis) in Ciliwung River, Indonesia. AACL Bioflux 2014, 7, 33-42.

36. Elfidasari, D.; Nurul-Ismi, L.; Putri-Shabira, A.; Sugoro, I. The Correlation Between Heavy Metal and Nutrient Content in Plecostomus (Pterygoplichthys pardalis) from Ciliwung River in Jakarta. Biosaintifika J. Biol. Biol. Educ. 2018, 10, 597-604. [CrossRef]

37. Elfidasari, D.; Nuril-Ismi, L.; Sugoro, I. Heavy metal concentration in water, sediment, and Pterygoplichthys pardalis in the Ciliwung River, Indonesia. AACL Bioflux. 2020, 13, 1764-1778.

38. Jinadasa, B.K.K.K.; Ariyarathne, D.S.; Ahmad, S.B.N. Trace Metal Contaminants in Tissues of the Orinoco Sailfin Catfish Pterygoplichthy smultiradiatus, (Hancock, 1828). Sri Lanka Nat. Sci. 2014, 12, 1-4.

39. Kong-Yap, C.; Jusoh, A.; Leong, W.J.; Karami, A.; Hock-Ong, G. Potential human health risk assessment of heavy metals via the consumption of tilapia Oreochromis mossambicus collected from contaminated and uncontaminated ponds. Environ. Monit Assess 2015, 187, 584. [CrossRef]

40. Hossain, I.; Saha, B.; Begum, M.; Jahan-Punom, N.; Begum, K.; Shamsur-Rahman, M. Bioaccumulation of heavy metals in nile tilapia Oreochromis niloticus (Linnaeus 1758) fed with commercial fish fee. Bangladesh J. Sci. Res. 2016, 29, 89-99. [CrossRef]

41. Rafati-Rahimzadeh, M.; Rafati-Rahimzadeh, M.; Kazemi, S.; Moghadamnia, A. Cadmium toxicity and treatment: An update. Casp. J. Intern. Med. 2017, 8, 135-145. [CrossRef]

42. Souza-Arroyo, V.; Martínez-Flores, K.; Bucio-Ortiz, L.; Gómez-Quiroz, L.E.; Gutiérrez-Ruiz, M.C. Liver and Cadmium Toxicity. J. Drug Metab. Toxicol 2012, S5, 1. [CrossRef]

43. European Commission. Commission Regulation (EC) No 1881/2006 of the European Parliament and the Council of 19 December 2006 Setting Maximum Levels for Certain Contaminants in Foodstuffs. Off. J. Eur. Communities. 2006, L364, 5-24.

44. Official Diary. NORMA Oficial Mexicana NOM-242-SSA1-2009, Productos y Servicios, Productos de la Pesca Frescos, Refrigerados, Congelados y Procesados, Especificaciones Sanitarias y Métodos de Prueba, Official Gazette of the Federation Mexico, 10 February 2011. 2009. Available online: http:/ / dof.gob.mx/nota_detalle.php?codigo=5177531\&fecha=10/02/2011 (accessed on 12 May 2021).

45. USFDA. Fish and Fishery Products Hazards and Controls Guidance; Center for Food Safety and Applied Nutrition's; US Food and Drug Administration: College Park, MD, USA, 2001.

46. SNI. Standardisasi Nasional Indonesia. Indonesia National Standard. In Maximum Limits for Heavy Metal Impurities in Food; Badan Standardisasi Nasional: Jakarta, Indonesia, 2009.

47. SNI. Standardisasi Nasional Indonesia. Indonesia National Standard. Chemical means of trials section 6: The heavy metal levels Lead $(\mathrm{Pb})$ and Cadmium (Cd). In Fishery Product; Badan Standardisasi Nasional: Jakarta, Indonesia, 2011.

48. World Health Organization (WHO). Health criteria other supporting information. In Guidelines for Drinking Water Quality, 2nd ed.; WHO: Geneva, Switzerland, 1996; pp. 31-388.

49. WHO. Exposure to Cadmium: A Major Public Health Concern; World Health Organization: Geneva, Switzerland, 2010. 